\title{
The Change Project Approach: A response for reorienting teacher education to address Education 2030 in southern Africa - The case of Midlands State University, Zimbabwe
}

\author{
Shepherd Urenje, Uppsala University, Sweden; Million Chauraya, Midlands State University, \\ Zimbabwe; Charles Chikunda, UNESCO Regional Office for Southern Africa, Zimbabwe
}

\begin{abstract}
The change project approach could be applied to enhance teacher education for the purpose of confronting 21st Century challenges through education (Education 2030). The challenge for teacher education institutions is to prepare future teachers with the socio-ecological knowledge, skills, attitudes and values essential for sustainable living, by reorienting current unsustainable ways of thinking and doing. This can be achieved by integrating Education for Sustainable Development (ESD) and in a number of teacher education programmes in southern Africa, teacher educators have begun to do this. This paper discusses the critical role of a change project approach in creating the social transformation processes and actions required to achieve the ambitions of Education 2030. Cases from the Midlands State University in Zimbabwe have demonstrated important efforts to reorient university curricula. The paper investigates and discusses the challenges associated with reimagining teacher education and key considerations that need to be addressed to achieve the goal of Agenda 2030.
\end{abstract}

Keywords: Change project approach; social transformation; Education 2030; Education for Sustainable Development

\section{Introduction}

Institutions of higher education are powerful means by which society can create more sustainable futures. This can happen when teaching, learning and research are reoriented to incorporate the concept of Education for Sustainable Development (ESD) to address many of the current problems associated with human development. People and communities in southern Africa are exposed to a host of vulnerabilities as a result of rapidly degrading social, economic, and ecological environments, characterised by poverty, social decadence, increased droughts, desertification, and the more frequent occurrence of extreme weather events such as mass flooding. Recently, efforts to confront COVID-19 have spawned a myriad military metaphors and connotations including the "greatest challenge since the 
Second World War", "working on the frontline" and the virus being seen as an "invisible enemy" (Harris, 2020). Global crises tend to induce reflections on the relevance of education and hence the importance of attaining target 4.7 of the Sustainable Development Goal number 4 (SDG 4) on quality lifelong education. Given the quality of education accessible to the majority in southern Africa, people have not been empowered to adapt sustainably to, mitigate against or cope with the complexity of emergent issues in their environments.

According to UNESCO (2015), a good quality education empowers people to change the way they think and act in relation to a sustainable future. When sustainable development issues are integrated into all aspects of teaching, learning and research, institutions of higher education have the potential to transform society and develop students who are change agents, young people capable of transforming how society operates. In this paper we suggest that when teacher education is reoriented towards sustainability, through the principles of ESD, it has the potential to enable social transformation towards sustainable livelihoods. Our inability to address current environment and sustainability challenges reflects the way in which the current generation has been educated. Our priorities should focus on rethinking teacher education to help students think and behave in different ways that foster sustainable lifestyles, human rights, gender equality, promotion of a culture of peace and non-violence, global citizenship and appreciation of cultural diversity. Teacher education institutions are therefore charged with the task of equipping students with essential knowledge, skills, attitudes and values empowering them to participate in creating a sustainable future and this can be achieved through transformative learning approaches (Urenje, 2020). This is a learning process in which previously held assumptions and interpretations are challenged and revised in order to guide future action (Mezirow, 1996). This means un-learning unsustainable practices that society has taught us, relearning sustainable practices of the past and learning new ways of thinking and acting.

The effectiveness of the quality of teacher education and its relevance for the 21st Century is questionable given the struggle to demonstrate the competences for reorienting current teaching and learning. Its preparedness to mould a new cadre of teachers that would enable effective education for development is doubtful. The purpose of this paper is therefore to bring to light how the change project approach could enhance teacher education for the purpose of confronting 21st Century challenges by fulfilling the aspirations of Education 2030, particularly SDG 4. The paper shares experiences gained in a nine-month pilot programme on capacity development for Agenda 2030 (March-November 2019) designed to support the integration of ESD across the university formal education system in Zambia and Zimbabwe. The programme was funded by the Swedish Institute and jointly coordinated by the Swedish International Centre of Education for Sustainable Development (SWEDESD), Sweden (northern key partner) and the Copperbelt University, Zambia (southern coordinating partner). It was implemented in six universities in Zambia and Zimbabwe. This paper will focus on the case of a change project implemented at Midlands State University (MSU) in Zimbabwe as an outcome of the pilot programme. 


\section{Background and context}

At the end of 2015 the United Nations adopted 17 sustainable development goals (SDGs), UN Agenda 2030, and emphasised that education is a powerful tool and driver to help attain these SDGs by ensuring an inclusive quality education and promoting lifelong opportunities for all. Teacher education should therefore support teachers in developing competences that fulfil the objectives related to sustainability so as to address our 21st Century challenges. When we apply the SDGs to the Southern Africa Development Community (SADC) region and Zimbabwe in particular, we link development priorities to a comprehensive policy agenda in a way that creates synergy and establishes a more effective response to regional and national challenges including poverty, health, sanitation, energy, employment, economic growth and environmental protection. Education is a critical component of this agenda for two reasons. Firstly, it is a goal in itself i.e. SDG 4 is oriented towards the achievement of educational quality within a lifelong learning framework. Secondly, education makes it possible to support the other goals, bringing a new focus and importance to education, learning processes and curricula. In particular, target 4.7 of SDG 4 draws attention to the relationship between ESD and educational quality. Zimbabwe's educational response has been through two ministries, the Ministry of Primary and Secondary Education (MoPSE) in charge of Basic Education, and the Ministry of Higher and Tertiary Education, Innovation, Science and Technology Development (MHTEISTD) responsible for teacher education.

Two landmark developments can be seen as a response to the 21st Century challenges in Zimbabwe. Firstly, in their efforts to enhance the quality and relevance of education, MoPSE embarked on a comprehensive curriculum reform process in 2014. This culminated in a new competence-based curriculum framework which was finalised in 2015 and set for phased implementation in 2017. The competence-based curriculum seeks to foster lifelong learning compatible with opportunities emerging from 21st Century challenges, and empowering learners for life and work with essential competences of critical thinking, creativity and innovation, communication and collaboration, among others. Secondly, MHTEISTD has revised Zimbabwe's state universities' traditional tripartite mission of teaching, research and community service to align higher education to the urgent national ambition to attain middle income status by the year 2030. The result was Education 5.0, which now requires institutions of higher and tertiary education (including teacher education) to not only: (1) teach, (2) research and (3) serve the community, but also to (4) innovate and (5) industrialise. Under Education 5.0, universities and teacher education institutions must reorient their curricula towards problem-solving for value-creation. The two developments are important because teacher education in Zimbabwe now needs to reorient curricula to fulfil MHTEISTD's ambition of creativity and innovation and also the competence-based expectations of the MoPSE where their teachers will be employed.

In the 2015 Education for All report, UNESCO argued that "ESD enhances the relevance of education, thus enhancing educational quality" (p. 206). Not only does ESD enhance the relevance of the content in education, but it also supports "transformative, active learning pedagogies and it foregrounds values of equity, peace, sustainability, ecological integrity 
and social justice in education" (UNESCO ROSA, 2018, p. 3). Teacher education is charged with the task of nurturing 'educated citizens' who should be critical thinkers, creative and ethical persons who live in a sustainable way and care for the well-being of humanity and the environment. One of the major issues highlighted in the Global Education Monitoring Report (2016) is that teacher education needs to be more comprehensively aligned with the SDGs, and teachers need to be supported to understand and implement ESD. The same issue was raised at the end of the UN Decade of Education for Sustainable Development (2005-2014) at the World Conference on Education for Sustainable Development held in Aichi-Nagoya in 2015. (UNESCO ROSA, 2018, p. 3)

The purpose of this paper is therefore to bring to light how teacher education can be reoriented for the purpose of confronting 21st Century challenges by aligning the aspirations of Education 2030, SDG 4, MHTEISTD Education 5.0 and MoPSE's new competence-based curriculum. We use the change project approach to illustrate how MSU is reorienting their teacher education curriculum to fulfil the objectives of the pilot programme regarding capacity development for Agenda 2030.

\section{The change project approach}

The pilot programme regarding capacity development for Agenda 2030 in Zambia and Zimbabwe centred on an action learning intervention, the change project, designed to act as a catalyst to support transformative innovations towards sustainability in teacher education. We describe the change project as an institutional change initiative, which is collectively developed with the dean of the Faculty of Education, teaching and support staff. The learning processes and the momentum of the change project should remain in the institution even when the individuals who participated in the actual training have moved to other places. Each partner institution was responding to their institutional current and future demands in line with national and global sustainability trends. These methods and processes are applied in three action research cycles (see Figure 1).

Figure 1: Change project action research cycle (Rumjaun \& Urenje, 2017)

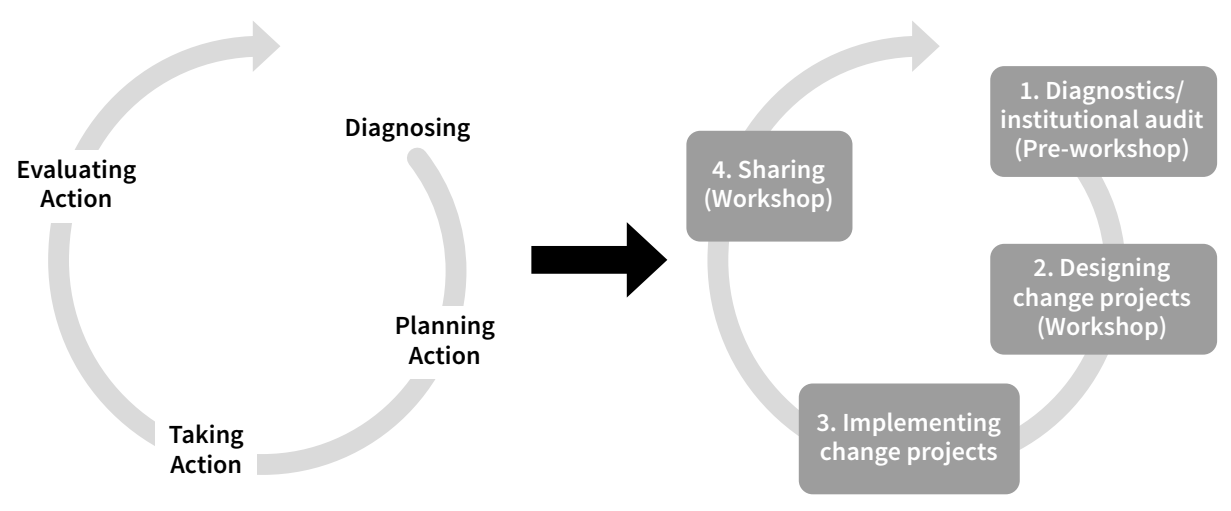


Each institution participating in the pilot programme in Zambia and Zimbabwe was expected to design a change project "to reorient education and learning so that everyone has the opportunity to acquire the knowledge, skills, values and attitudes that empower them to contribute to sustainable development - and make a difference" (UNESCO, 2014, p. 14). The change project responds to the following two questions:

1. How can current teaching and learning be transformed in order to respond to the 21st Century Agenda 2030 challenges?

2. How can we use ESD teaching and learning approaches to transform teacher education in ways that empower student teachers (and practising teachers) for Agenda 2030 and beyond?

We chose to work with action research as its methodology enables practitioners to integrate their actions of implementing change while at the same time developing an understanding of the effectiveness of this implementation in an iterative manner. According to Alsop, Dippo and Zandvliet (2007), it is possible for practitioners (in our case, teacher educators) to examine closely their role as change agents and decision-makers through their own problematisation of the teaching and learning processes within their work contexts, and through their own reflexive practice (Hong \& Lawrence, 2011). As a way of enabling teacher educators to interrogate their current practice, we followed a four-step cycle (see Figure 2) of action research developed by Coghlan and Brannick (2001):

1. Diagnostics - entails assessing the institution to identify issues that require action leading to improvements. An institutional audit is undertaken.

2. Designing the change project - in the next step the problem issue is identified, understood and isolated. This may require a workshop to plan and design the change project to confront the problematic issue.

3. Implementing the change - the project design and strategy must be implemented. It is important to monitor, evaluate and draw lessons from the implementation.

4. Sharing - this represents the last step of the action cycle whereby staff involved in the implementation of the change project get together in a workshop to share their experiences regarding embedding the change project in their institutions.

Coghlan and Brannick (2001) proposed two cycles for action research projects: a 'core action research cycle', which refers to the aims or content of the research project and a 'thesis action research cycle' or 'meta-learning cycle' which relates to how the project itself is implemented. A third cycle (Figure 2) emerges within the meta-learning cycle, which is the implementation and scaling (institutionalisation) of their change project ideas (Rumjaun \& Urenje, 2017). With respect to the pilot programme for capacity development, these three action research cycles, (planning, execution and implementation or institutionalisation) are discussed below. 


\section{Core and thesis research cycles}

\section{Cycle 1: Planning - The core action research cycle}

The core action research cycle took the form of an institutional dialogue and a pre-course assignment. This step was divided into two parts: (1) a planning workshop for leaders and policy makers in teacher education, and (2) a pre-course assignment in preparation for the first training session. The planning workshop in March 2019 was a collective planning activity with programme partners from Zambia and Zimbabwe to develop the course. The workshop was designed as a dialogue between ministries of education and higher education, government directors responsible for teacher education, university deans responsible for teacher education, and SADC ESD experts and facilitators. There were two outcomes from this workshop:

1. A commitment by participating ministries and universities to support the training and implementation processes during, and more especially after, the official training programme.

2. A capacity building or training outline and an agenda for learning support material to be developed.

Commitment from the deans and ministries of education formed part of an essential context for change projects based on a pre-course assignment which responded to the following:

1. What role can teacher education play in national ESD processes and Agenda 2030?

2. What is currently working well in our institution? How can we make it even better?

3. What is not working so well? How can we make it work better?

Based on these three questions, participants from each university were supported in developing a draft plan for their change projects, in relation to Agenda 2030. This precourse assignment opened up the potential of universities as active participants to support national and regional aspirations of Agenda 2030. The assignment also showed the steps necessary to strengthen institutions in managing change processes. Three participants from each institution took the lead in completing this assignment and in representing the university in the regional workshops for capacity development. 
Figure 2: Core and meta learning cycles adapted from Coghlan and Brannick, 2001 (Rumjaun \& Urenje, 2017)

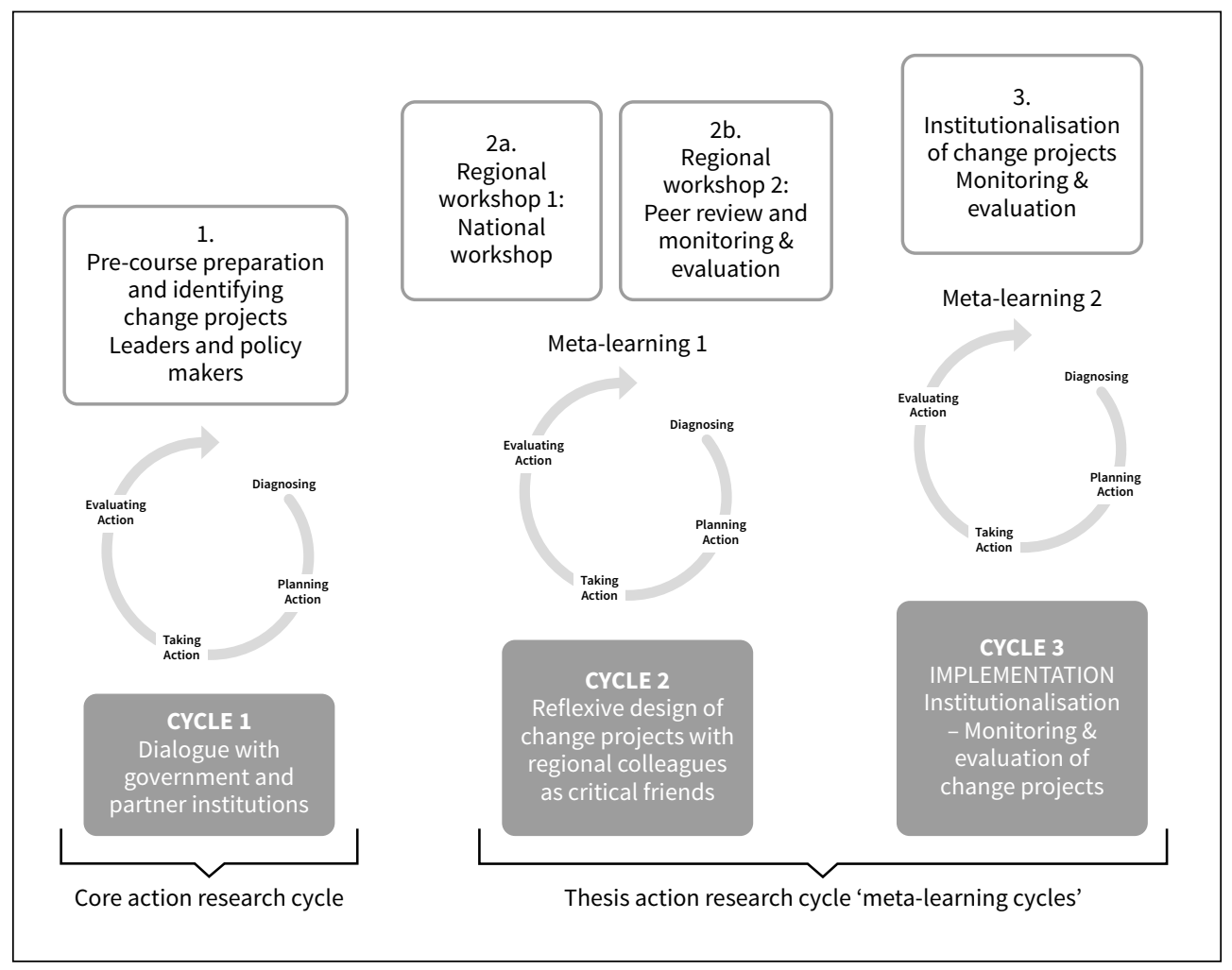

\section{Cycle 2: Execution - Thesis action research cycle (Meta-learning 1)}

After Core Action Research Cycle 1, the next step was to deepen and co-design planned strategies in the form of intra-country and inter-country dialogues between and among the institutions in Zambia and Zimbabwe (2a and 2b in Cycle 2 in Figure 2). This was done in three steps of two regional workshops (one in April and the other in November) and one country workshop (in July) (see Figure 2). In the first regional workshop, three participants from each university were supported to develop implementation plans for their change projects. Secondly, a national workshop was conducted for the three universities in each county during which the participants focused on adjustments to their implementation plans in close dialogue with their colleagues and superiors. This dialogue strengthened partnerships among relevant stakeholders in the university and refined the implementation plan in line with the principles of collaborative learning. In addition, at least one workshop was conducted at each university.

In the second regional workshop, participants came together again to report on progress, engage in monitoring and evaluation, ongoing action planning and scaling of their innovations. This process was devoted to finalisation of the change project outline 
with co-participants as critical friends and with support from programme coordinators and regional resource people. During this step, participants completed a first cycle of the thesis action research cycle, meta-learning 1 (see $2 b$ in Figure 2) of evaluation, learning and revision of their change projects. Subsequently, change project reports were collated by the project coordinators and synthesised for sharing with other participants, professionals in the field and future participants. Participants were encouraged to further develop and implement their change project, and to use their experiences and reports to make presentations at international, regional and local conferences where appropriate. The outcome of this learning cycle was a detailed implementation plan, complete with methods and approaches for evaluation and reporting on the project. Having discussed change project reports in the regional workshop, the cycle was completed by engaging participants in a reflexive process of testing and monitoring of transformational changes in their own practice. This also extended participants' access to colleagues from another countries and institutions they may not have worked with. This open access enabled them to establish collaborative partnerships for identifying further issues in their institutions and for developing processes for improvement. In so doing, they became aware of alternative ways of viewing and approaching educational questions, which opened new ways for examining their own practices.

\section{Cycle 3: Institutionalisation of change projects (Meta-learning 2)}

After the second and final regional workshop in Cycle 2(b), the project was no longer in direct control of changes taking place in the institutions. We will however continue to support collaboration between and among institutions through an informal e-learning network. In Cycle 3, the change project was strengthened by anchoring it in the home institution, renewing support from superiors for the implementation plan, and strengthening engagement of colleagues to form an institutional team for change. The programme suggests a second round of dialogue and critical reflection within the institution to which participants, colleagues and other interested parties are invited. The outcome of this phase is a presentation of how the change project is being situated in the work context which can be shared in the form of a poster, video or document.

A UNESCO ROSA web platform, which has been developed as a support mechanism for the Sustainability Starts with Teachers project, will provide a forum for support to the participants through, for example, enhanced possibilities for networking and peer support interactions. Participants will be encouraged to publish their project work as action research (this paper on MSU being an example). Through email and web-based support, there will be ongoing interaction between resource people, participants and their institutions.

For evaluation, we used the Value Creation Framework of Wenger, Traynor and De Laat (2011), which requires the development of a value creation narrative for participants over time. The framework offers a tool for evaluation of social learning processes, and it is an appreciative approach to evaluation, that can also stimulate reflexivity and (further) change. In our case, the framework was used to design and develop indicators for the 
outcomes of transformative learning; these emerged from a critical review of the value creation narratives via wider synthesis and deliberative engagement. The framework that is made up of five cycles is summarised in Figure 3.

Figure 3: Value creation framework adapted from Wenger, Traynor and De Laat (2011)

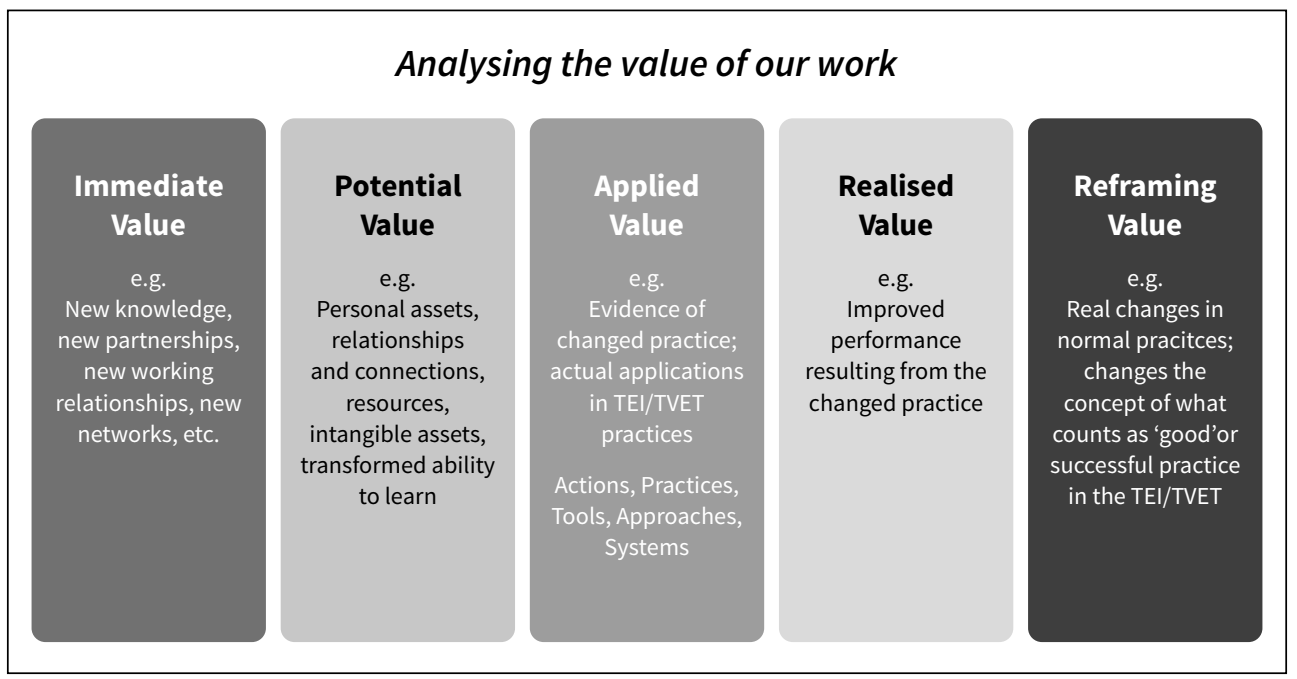

\section{The Midlands State University change project outcomes}

MSU is one of the three universities from Zimbabwe that participated in all the cycles of the change project pilot programme described above. Four members of the Faculty of Education, including the dean, participated in the programme. The dean and one member of the Faculty participated in Cycle 1 planning phase workshop. Upon their return they held a Faculty workshop to introduce the concept of a change project approach in rethinking and rebranding the Faculty curriculum and practices in response to the goal of integrating ESD and other pressing national priorities in the education system. The workshop initiated thinking about potential change projects and motivated Faculty members to rethink their practices especially in relation to ESD.

\section{The genesis of the MSU change project}

The change project was concretised prior to and during the pilot programme's first regional workshop in April 2019. Three members from the Faculty met several times to deliberate on a possible change project using the pre-course assignment and the change project template provided for the workshop preparation. Three shifts in the education system influenced the development of the change project significantly. Internationally, the need to integrate ESD in school curricula provided insights into how the teacher education curriculum at MSU needed to respond to this shift. Nationally, the team considered the introduction 
of the competence-based curriculum in 2017 and the Ministry of Higher Education's call for Education 5.0 to be integrated in and inform university's curricula and practices. Primarily, the project was designed to reconfigure the education and training model in the Faculty of Education by aligning courses to provide graduates with skills, knowledge, values and attitudes for addressing 21st Century challenges. The overall intention was to improve existing education practices in the light of emerging national and global socioeconomic trends. The project also sought to bring about changes in the teacher preparation programmes in the Faculty, so as to produce teachers who are knowledgeable about ESD, the competence-based curriculum, and Education 5.0, specifically in terms of the philosophy, broad goals and implementation implications of these innovations. The initial ideas on this change project were presented at the first regional workshop of the pilot programme in April 2020 and feedback helped to refine the project.

\section{Features of the refined change project}

After the first regional workshop, the MSU project team held several meetings to refine the change project and agree on implementation. Based on the intentions of the change project outlined above, it focused on developing 'The teacher we need for the 21st Century and beyond'. The Zimbabwean competence-based school curriculum emphasises the development of competencies and values such as problem solving, critical thinking, decision making, innovation, technology literacy, conflict management, teamwork, enterprise development, cooperation, self-respect and respect for others, self-discipline, accountability and commitment to others (Ministry of Primary and Secondary Education, 2014). The curriculum also calls for the integration of topical global issues (presented as cross-cutting themes) such as gender equity, health issues, food security, technology, environmental issues, and disaster and risk management in the teaching of the different learning areas. Thus, the MSU's change project is concerned with re-designing or reconfiguring the teacher education curriculum with the goal of producing teachers with the above knowledge and competencies, for their needs as teachers in Zimbabwean schools and for their personal needs as functional citizens in the 21st Century.

Specifically, the project is introducing changes in the following aspects of the teacher education curriculum: revising module outlines so that they integrate ESD issues and 21st Century competencies; changing lecturers' instructional pedagogy so they model the teaching methodology that teacher education graduates are expected to implement in schools; changing assessment formats so they measure the development of lifelong competencies and knowledge of global issues; and guiding students' research projects towards substantive curriculum and global issues. Furthermore, lecturers are encouraged to shift from presenting formal lectures, and engage in active learning pedagogies such as involving students in investigations, presentations, debates, problem solving activities, and analysis of live case studies. 


\section{Implementation of the change project}

The refined change project was presented in a workshop for all Faculty of Education lecturers at MSU in August 2019. The workshop aimed to encourage lecturers to adopt the change project as a Faculty project, and to agree on implementation modalities and targets. Another objective was to highlight areas of the teacher education programmes that needed to be changed. Action plans were agreed on for implementation during the August to November 2019 semester. These included rebranding module outlines so they reflected the ideals of the changed teacher education curriculum; enacting active learning pedagogies in lectures; and using assessment formats and tasks that support sustainable development competencies and knowledge in student teachers.

Following implementation from August 2019, the change project was presented at a country workshop held in September 2019. Useful insights were obtained from this workshop, specifically the need to think about scaling the project to institutional level. The change project was then presented at the second regional workshop in Lusaka, Zambia, in November 2019. While the project was generally accepted as a viable change project that could transform the teacher education curriculum at MSU, participants encouraged ongoing implementation and thinking about ways of addressing the following: monitoring implementation progress; ongoing evaluation of the impact of the changed curriculum on the student teachers in terms of the developing knowledge, competencies and values; scaling the project to institutional level; and networking with other teacher education institutions for purposes of sharing successes and developing a systemic approach to education as a whole.

It was the intention of the project team to hold another faculty workshop early in 2020, so as to review implementation progress and to integrate suggestions made at the workshops described above. The COVID-19 lockdown that began in March 2020 meant the workshop was delayed and it was ultimately held virtually in September 2020. Following presentations from two members of the project team to refresh understanding of the faculty change project, most of the time was spent in a plenary discussion concerning implementation updates from members, strategies for monitoring progress, ways of evaluating students' learning outcomes under the changed curriculum, strategies for scaling the project to institutional level, and how to network with other institutions in the education system.

The overall observation was that there had been little progress in implementing the project. However, two cases gave insights into how the change project could be implemented as planned. The first case involved one of modules, Community Development, in Adult Education, in which for purposes of continuous assessment, students were expected to identify and find ways of solving a community problem. For assessment purposes, the students were expected to produce a write-up in the form of a report on what they would have done. They were also expected to compile a file, describing the process (with pictures) from problem identification to strategies used to resolve the problem and the impact of the intervention. Lecturers in the section visited the site to assess on the ground what 
the student would have done. A specific example was given of a student in a rural area who identified poverty and hunger as the problems facing the community. The student approached an NGO to partner him in developing income and food generating projects such as market gardening, rabbit keeping, poultry projects and goat keeping in the community, which is now benefiting from these projects.

The second case involved the Textiles and the Environment module in Textiles Technology and Design, in which students are expected to identify any problem in society to investigate and develop solution strategies. A write-up of what the student would have done constitutes the continuous assessment for the module. In both the modules cited above, students were expected to write a formal examination for summative assessment purposes.

While it was acknowledged that the two modules exemplified the ideals and goals of the change project, some matters were raised which members felt could be working against achieving the goals of the project. Firstly, it was felt that the change project should not be limited to specific modules. Efforts should be made to implement the agreed changes across all modules and programmes. Secondly, it was observed that using final written examinations as part of assessment in modules such as those described above shifted the students' focus from the competencies to be developed in the module, to memorising notes for purposes of passing the course. Where examinations are involved, students tend to expect formal lectures and written notes from the lecturer. The major concern becomes passing the examinations rather than developing competencies in action research and active learning. Hence there was a consensus that in some modules, written examinations should be dropped and that certain modules use continuous assessment only. Such assessment could involve artefacts made by students, presentations on results of investigations, debates on issues that are considered pertinent in communities, reports on learning activities that the students would have engaged in. This would assess substantive knowledge and competencies that are consistent with the 21st Century competencies.

The plenary discussion also focused on mechanisms for monitoring the implementation of the change project. It was agreed that existing managerial structures in the different departments of the faculty would monitor how individual lecturers are implementing the change project. Reports on implementation progress and challenges would be presented in the next faculty workshop. In terms of evaluating students' learning outcomes, lecturers were encouraged to shift from written assessments (such as routine assignments and tests) to assessment tools that measured acquisition of significant competencies such as those agreed on in the project. For purposes of scaling up the project to the whole university, an interdisciplinary approach was suggested. For example, lecturers in the Science subjects within the Faculty of Education could link up with lecturers in the Faculty of Science and share their efforts and successes of integrating ESD into their modules. It was also agreed that success stories within the Faculty would be shared by way of university-wide platforms such as Senate reports and on the university website through the Department of Information. There was insufficient time at the workshop to deliberate on strategies for networking with other teacher education institutions, and for ensuring sustainability. It 
was agreed that these would be discussed in the next workshop, the main focus of which would be reviewing the implementation progress of the change project.

\section{Evidence of value created by the MSU change project approach}

As noted, evaluation was done using Wenger et al.'s (2011) Value Creation Framework. Firstly, there was evaluation at the end of workshops and secondly, a few months into the implementation of the change project as a way of monitoring the transformation process. End of workshop evaluation was designed to gain insight into which aspects of the workshops were most valuable for change project participants, and into the potentially transformative aspects of the workshop for individuals and institutions. Some participants' responses are reflected in Table 1 below.

Table 1: Evidence of value created by the change project approach at MSU

\begin{tabular}{|c|c|}
\hline Value created & $\begin{array}{l}\text { Value creation narrative } \\
\text { Evidence: What value is being created for you and your institution in the change project? }\end{array}$ \\
\hline $\begin{array}{l}\text { Immediate value } \\
\text { New partnerships, } \\
\text { relationships, } \\
\text { knowledge, } \\
\text { networks }\end{array}$ & $\begin{array}{l}\text { The workshop was valuable to me because I now have a different perspective when viewing } \\
\text { education. I now view education as an industry not as a profession. } \\
\text { I gained new knowledge that change is not an event but a process which is not easy. } \\
\text { The project has sharpened my focus and insights on challenges before us in an attempt to } \\
\text { realise quality education. } \\
\text { The content on SDGs and agenda } 2030 \text { was very helpful. }\end{array}$ \\
\hline $\begin{array}{l}\text { Potential value } \\
\text { Personal 'assets' } \\
\text { (new knowledge, } \\
\text { new partnerships, } \\
\text { resources) } \\
\text { Transformed ability } \\
\text { to learn and bring } \\
\text { about changes }\end{array}$ & $\begin{array}{l}\text { As a Department and Faculty we agreed to reconfigure the education model so that students } \\
\text { exit with valuable skills, knowledge, attitudes and values which were not there before the } \\
\text { workshops. } \\
\text { My management and presentation skills were improved. } \\
\text { The project is bound to bring about change in pedagogy. } \\
\text { The faculty members benefited from our presentations which we did after the workshops, } \\
\text { which helped them to be well versed with the new shift in the education system. } \\
\text { Our change project might contribute greatly towards the vision of the institution by improving } \\
\text { the quality and relevance of education through producing students who are innovative and } \\
\text { industrious. } \\
\text { I have come to appreciate the importance of interdisciplinary approach in initiating change. } \\
\text { The workshop revitalised need to align programme content to the ministerial framework of } \\
\text { Education 5.0. }\end{array}$ \\
\hline $\begin{array}{l}\text { Applied value } \\
\text { Any evidence of } \\
\text { changed/changing } \\
\text { practice. Any } \\
\text { tools developed, } \\
\text { approaches } \\
\text { changed/changing } \\
\text { in systems }\end{array}$ & $\begin{array}{l}\text { We restructured the modules and module outlines. These were very useful materials because } \\
\text { when we rebranded the modules the aim was to meet the demands of the } 21 \text { st century which } \\
\text { is very crucial. } \\
\text { I have shifted from being a dry academician to embrace liberating pedagogy. } \\
\text { I have shifted from lecturing to active learning pedagogy. }\end{array}$ \\
\hline
\end{tabular}




\begin{tabular}{|l|l|}
\hline Value created & $\begin{array}{l}\text { Value creation narrative } \\
\text { Evidence: What value is being created for you and your institution in the change project? }\end{array}$ \\
\hline $\begin{array}{l}\text { Realised value } \\
\text { Any evidence } \\
\text { of changes in } \\
\text { performance }\end{array}$ & $\begin{array}{l}\text { Some of our students have already started working on various products using the available } \\
\text { resources and generating income which is good. Some of the problems in the food industry } \\
\text { like food loss are being addressed because of that change project. } \\
\text { In the Department, assignment tasks and examination items are showing a shift towards } \\
\text { embracing 21st Century challenges. }\end{array}$ \\
\hline $\begin{array}{l}\text { Reframed value } \\
\text { Significant changes } \\
\text { in the institution/ } \\
\text { programme }\end{array}$ & No evidence as yet of sustained changes that can define success. \\
\hline
\end{tabular}

As shown in Table 1, the Value Creation Framework provides a useful tracking mechanism for understanding how the change processes have been influenced by the pilot programme, as well as showing insight into aspects of the change project itself that have transformative potential. This offers a cumulative (formative) perspective on the overall value being created for participants and institutions over the life of the programme. From this, it is possible to track influences from the pilot programme process and content back to the reflexive changes made to the change project plans and the change projects themselves.

\section{Discussion}

The core and thesis research cycles outlined in the section above are used as a framework for discussion to analyse the professional and institutional developments taking place at MSU as a result of the change project intervention. The Value Creation Framework (Wenger et al., 2011) is also used to develop an emerging value creation narrative at MSU as demonstrated by transformative learning processes arising from wider synthesis and deliberative engagement.

\section{Cycle 1: The core action research cycle}

A major accomplishment of the change project approach was its endorsement and acceptance by the Ministries of Education and the six universities in Zambia and Zimbabwe. Stakeholders confirmed the value this brings to ongoing education and teacher education reforms. Apart from complementing initiatives to achieve Agenda 2030 in adopting 21st Century learning outcomes in education and training, the partnership has created and enhanced opportunities for both North-South cooperation between Sweden and the SADC region, and for an education and research network promoting South-South cooperation between Zambia and Zimbabwe. These features enabled mutual exchange, sharing and co-learning among programme participants. Firstly, during the planning workshop that initiated the change projects, a co-creation approach facilitated dialogue among directors in Ministries of Education, deans responsible for teacher education, and faculty members. Their advice ensured a fit and relevance of the project to the policy context of national and institutional reforms and existing transformation initiatives in education and teacher 
education. Secondly, principles put in place meant that the change projects recognised policy, engaged leaders, building on existing strengths and networks, with a focus on value addition and impact creation. Thirdly, the programme appeared to work because it focused on and profiled creativity and ESD innovation from the onset, and foregrounded an agenda for learning. We learnt from MSU that it created self-belief among participants and raised their awareness of Agenda 2030, the SDGs, ESD, and 21st Century learning outcomes and how they relate to quality and relevance of education and teacher education.

\section{Cycle 2: Thesis action research cycle (Meta-learning 1 - Access to a community of critical friends)}

While there are generally many programmes for professional development for teachers in the SADC region, there are few professional development strategies for teacher educators (professors and lecturers) responsible for preparing the teachers for service. This constitutes a serious gap. The thesis action research cycle or meta-learning 1 (Figure 2) was designed to deepen and co-design teaching and learning strategies for the 21st Century in the form of intra-country and inter-country dialogue between and among the institutions in Zambia and Zimbabwe. Lack of continuous professional development and learning communities in teacher education was evident from the onset of the programme.

Four levels of professional access were identified:

1. Institutional level, as linkages were established across subject disciplines and departments;

2. National or inter-university level where change project leaders were in interaction with colleagues from University of Zimbabwe and Great Zimbabwe University;

3. Regional level between institutions from Zambia and Zimbabwe; and

4. International level between southern Africa and Sweden.

This programme enabled the interaction among teacher educators regarding teaching and learning for the 21st Century and this interaction influenced their professional development. The MSU experience indicated that teacher interactions triggered by change projects helped with professional development in several ways: enhancing reflection on teaching practice, establishing a professional discourse community, raising the standards for teaching performances, and facilitating collaboration across subject disciplines. In addition, participants had access to knowledge e.g. ESD principles and associated frameworks, like an alternative assessment framework of significant learning; access to information about 21st Century issues and competencies; and access to national policies like curriculum frameworks and visions.

\section{Cycle 3: Institutionalisation of change projects (Meta-learning 2)}

Emerging tensions as a potential source of change and development required a collective strategy to deal with the hegemony of curriculum status quo and curriculum transformation as sticking points. Regrettably, there is no necessary correlation between educational 
achievement and socially and environmentally benign sustainable behaviour, but rather the opposite (Orr, 2004). In this case, education can be viewed as being part of the problem of resolving environmental and sustainability issues of the 21st Century. Many universities in southern Africa are struggling with how to respond to the demands of the 21st Century including how to end epistemic violence and decolonise teacher education curriculum (Heleta, 2016). It appears MSU has been struggling with an efficient response to demands of the 21st Century, the competence-based curriculum in the schools and Education 5.0. Even though some practitioners were willing to effect change, they suffered from an action deficiency syndrome, an inability to take decisive action (Urenje, 2012). However, evaluation responses from practitioners at MSU indicate that emerging tensions could provide the potential energy for practitioners to confront historically accumulated structural tensions within the system (see some practitioners' responses in Table 2). Change projects enable emerging tensions between the status quo and change to be addressed by 1) abandoning business as usual ethic and trying out new varieties of teaching and learning (business unusual); 2) being critical of cosmetic changes that protect the status quo and opting for major transformative changes; and 3) moving away from simplistic sustainable development projects like recycling and gardening in favour of radical curriculum innovation. Table 1 showed how the Value Creation Framework provided a formative tracking mechanism for understanding how the change processes have been influenced by the pilot programme. Table 2 shows insights (from teacher educators at MSU) into aspects of the change project itself that have transformative potential.

Box 1: Emerging value creation narratives from MSU practitioners: Breaking out of action deficiency syndrome

- The project is bound to bring about change in pedagogy.

- The faculty members benefited from our presentations which we did after the workshops, which helped them to be well versed with the new shift in the education system.

- Our change project might contribute greatly towards the vision of the institution by improving the quality and relevance of education through producing students who are innovative and industrious.

- I have come to appreciate the importance of interdisciplinary approach in initiating change

- The workshop revitalised need to align programme content to the ministerial framework of Education 5.0

The challenge at MSU was how to include all departments in the change project given the existence of high levels of acceptance of the status quo. Regardless of the tensions arising 
from a new way of thinking and acting, however, a higher level of professional practice is also developing as a result of the catalytic agency of the change project approach. A combination of personal, relational and collective agency has started to unfold, sowing seeds for a superior level of professional practice, which can be referred to as Cumulative Professional Agency (Urenje, 2012). Through the change project approach, MSU participants have started to deliberate and fine-tune their capabilities to drive curricular and pedagogical changes, the outcomes of which are beginning to show in the change project aims and objectives as shown in Figure 4. (See features of refined project and Table 1 - evidence of value created by change project.)

Figure 3: Cycle 4: Monitoring and evaluation; value creation (Rumjaun \& Urenje, 2017)

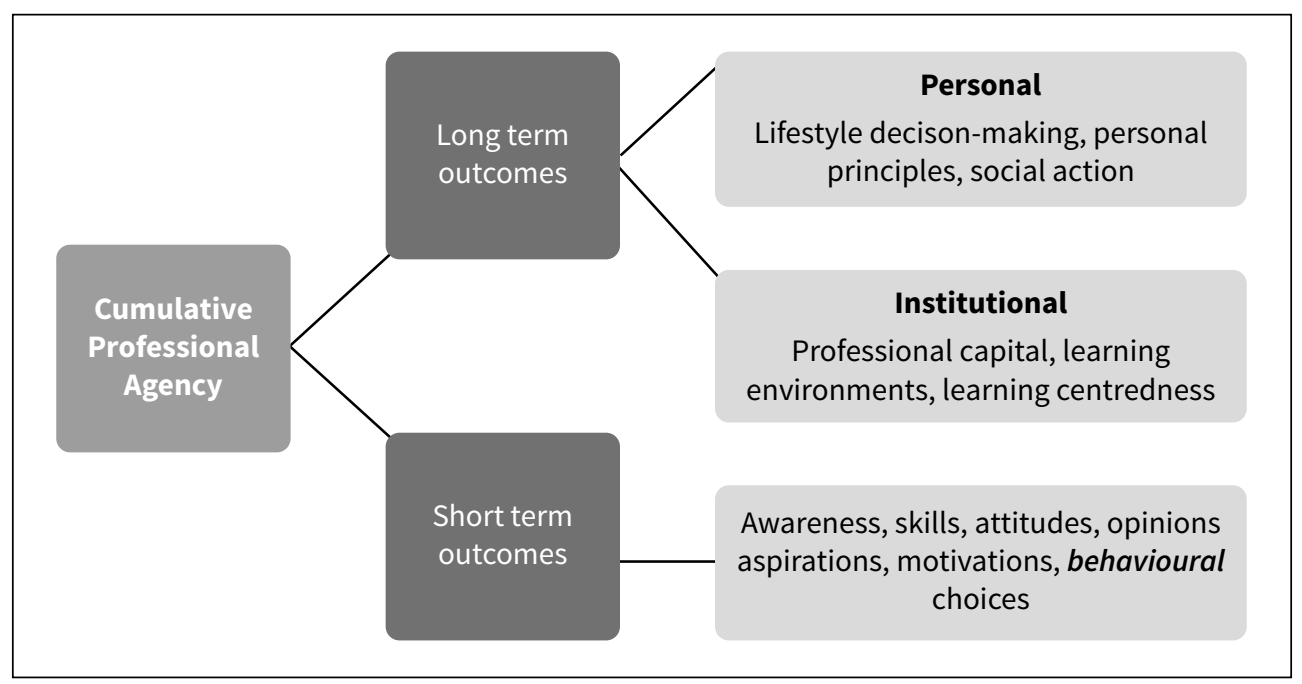

This cycle is still unfolding. Certain questions need to be considered. How do we keep the fire burning? How do we safeguard the lessons learnt, ensure continuing education effort (transformative learning efforts) for teacher educators as a way of safeguarding their skills of teaching and learning for social transformation and, in turn, boost their student teachers' outcomes?

\section{Conclusion}

This paper has explored how the change project approach could be applied to enhance teacher education for the purpose of confronting the 21st Century challenges through education. In the case of MSU, the change project approach can be thought of as a process of learning how to build the capacity of teacher educators for future-oriented thinking and acting, an example of implementing ESD across institutional disciplines with the potential to impact on achieving educational goals of quality and relevance, in line with Agenda2030 and SDG 4.7. Through the change project approach, MSU has initiated an intra- and inter- 
departmental dialogue to better understand the principles of using ESD for developing, constructing and implementing strategic plans for a competence-based curriculum; assessing and developing personal and institutional capacity to implement SDG 4; and analysing, enhancing and evaluating performance to better meet their stakeholder needs. The change project has been instrumental in enabling the institution to work with other SDGs, which emphasise essential knowledge, skills and attitudes to meet the challenges of creating a more sustainable world. Through this initiative, MSU has found a way of drawing the MoPSE (in charge of basic education) closer to the MHTEISTD (responsible for teacher education) in their common goal of responding to national aspirations for a competencebased curriculum - thus potentially creating value for the country as a whole. The paper has discussed the challenges and opportunities associated with reorienting teacher education and key considerations that need to be addressed to achieve the goal of Agenda 2030. The action research model opened up opportunities for future research in reorienting teacher education to meet the dynamic demands of the 21st Century.

\section{Notes on Contributors and their Contributions}

\section{Co-author}

Urenje, Shepherd

Dr Shepherd Urenje has a Doctorate in Education from the University College of London. He is a Programme Specialist in Sustainability Education for the Swedish International Centre of Education for Sustainable Development and is based at Uppsala University. His research interests include learning for social transformation and transforming teacher education.

\section{Co-author}

Chauraya, Million

Dr Million Chauraya has a PhD in Mathematics Education from the University of the Witwatersrand in South Africa. He is currently a Senior Lecturer in the Department of Science, Technology and Design Education at Midlands State University in Zimbabwe. His research interests include teacher education curricula and ESD.

\section{Co-author}

Chikunda, Charles

Dr Charles Chikunda has a PhD in Education for Sustainable Development from Rhodes University in South Africa. He is based in Zimbabwe from where he coordinates the UNESCO ESD Sustainability Starts with Teachers Programme in the SADC region. His research interests include ESD, global citizenship education and transformative education. 


\section{Percentage contribution}

\begin{tabular}{|c|c|c|}
\hline Areas of contribution & Author & $\begin{array}{c}\text { \% Contribution per area, } \\
\text { per author } \\
(\text { each area }=100 \%)\end{array}$ \\
\hline \multirow{3}{*}{ Conception or design of the paper, theory or key argument } & Urenje & $50 \%$ \\
\hline & Chauraya & $30 \%$ \\
\hline & Chikunda & $20 \%$ \\
\hline \multirow{3}{*}{ Data collection } & Chauraya & $55 \%$ \\
\hline & Urenje & $30 \%$ \\
\hline & Chikunda & $15 \%$ \\
\hline \multirow{3}{*}{ Analysis and interpretation } & Urenje & $34 \%$ \\
\hline & Chauraya & $33 \%$ \\
\hline & Chikunda & $33 \%$ \\
\hline \multirow{3}{*}{ Drafting the paper } & Urenje & $40 \%$ \\
\hline & Chauraya & $30 \%$ \\
\hline & Chikunda & $30 \%$ \\
\hline \multirow{3}{*}{ Critical review of paper } & Urenje & $34 \%$ \\
\hline & Chauraya & $33 \%$ \\
\hline & Chikunda & $33 \%$ \\
\hline
\end{tabular}

\section{References}

Alsop, S., Don Dippo, D. \& Zandvliet, D.B. (2007). Teacher education as or for social and ecological transformation: place-based reflections on local and global participatory methods and collaborative practices, Journal of Education for Teaching, 33(2), 207-223.

Coghlan, D. \& Brannick, T. (2001). Doing Action Research in your own Organization. London: Sage.

Global Education Monitoring Report (2016). Education for people and planet; Creating sustainable futures for all. Retrieved from https://www.eda.admin.ch/dam/deza/en/ documents/aktuell/news/20160923-weltbildungsbericht EN.pdf

Harris, A. (2020). COVID-19 - School leadership in crisis? Journal of Professional Capital and Community, 5 (3/4), 321-326. doi:10.1108/JPCC-06-2020-0045.

Heleta, S., 2016, 'Decolonisation of higher education: Dismantling epistemic violence and Eurocentrism in South Africa', Transformation in Higher Education 1(1), a9. doi: 10.4102/the.v1i1.9. 
Hong, C.E. \& Lawrence, S.A. (2011). Action research in teacher education: Classroom inquiry, reflection, and data-driven decision making. Journal of Inquiry and Action in Education, 4(2), 1-17.

Mezirow, J. (1991). Transformative Learning: Theory to Practice. New Directions for Adult and Continuing Education, 74, Summer 1997, Jossey-Bass Publishers.

https://www.ecolas.eu/eng/wp-content/uploads/2015/10/Mezirow-TransformativeLearning.pdf

Ministry of Primary and Secondary Education. (2014). Curriculum Framework for Primary and Secondary Education 2015-2022. Harare: Ministry of Primary and Secondary Education.

Orr, D.W. (2004). Earth in Mind: On education, environment, and the human prospect. Washington, DC: Island Press.

Rumjaun A.B. \& Urenje, S. (2017). Transforming Teacher Education for the 21st Century: Developing relevant competences for a changing world. Journal of Modern Education Review, 7(7), 488-511.

UNESCO. (2014). Roadmap for Implementing the Global Action Programme on Education for Sustainable Development. Retrieved from https://sustainabledevelopment.un.org/ content/documents/1674unescoroadmap.pdf

UNESCO. (2015). Education 2030. Incheon Declaration and Framework for Action: Towards Inclusive and Equitable Quality Education and Lifelong Learning for All. Paris. Retrieved from http://uis.unesco.org/sites/default/files/documents/education-2030-incheonframework-for-action-implementation-of-sdg4-2016-en 2.pdf

UNESCO ROSA (Regional Office for Southern Africa). (2018). Advanced Regional Training Programme in ESD for ECCE, Primary and TVET Teacher Educators in Southern Africa. Project Document. Harare: UNESCO ROSA, SWEDESD and Rhodes University Environmental Learning Research Centre.

Urenje, S. (2012). The role played by the International Training Programme in professional development and institutional competence in Southern Africa. Doctoral thesis, Institute of Education, University of London, London.

Urenje, S. (2020). Confronting the $21^{\text {st }}$ century global dysfunction through Education for Sustainable Development. In press. Available from Studia Periegetica:

https://studia-periegetica.com/resources/html/cms/MAINPAGE

Wenger, E., Trayner, B. \& De Laat, M. (2011). Promoting and Assessing Value Creation in Communities and Networks: A conceptual framework. The Netherlands: Ruud de Moor Centrum. 